\title{
A comparison of effects of body weight and feed intake on digestion in broiler cockerels with effects of tannins
}

\author{
BY SULTAN MAHMOOD \\ Department of Poultry Husbandry, University of Agriculture, Faisalabad, Pakistan \\ AND RON SMITHARD \\ Department of Biological and Nutritional Sciences, University of Newcastle upon Tyne, $N E 17 R U$
}

(Received 23 October 1992 - Accepted 29 January 1993)

\begin{abstract}
The effects of body size and feed intake on $\mathbf{N}$ digestibility, pancreas and liver weight, and digestive enzyme activities in male broiler chicks were compared with those induced by dietary tannins. Four groups (SSM, ad lib., pair-fed and young) of sixteen birds each ( 2 weeks old) were used as experimental animals. They were fed on experimental diets for 4 weeks, except the young group which were fed from age $15 \mathrm{~d}$ to $24 \mathrm{~d}$ only. Two isonitrogenous and isoenergetic diets with (SSM) or without salseed (Shorea robusta) meal (CONTROL) were used. SSM diet was fed ad lib. to SSM group and control diet was fed ad lib. to ad lib. and young birds and to pair-fed birds at same intake level as SSM birds. Birds fed ad lib. utilized their diet more efficiently than the SSM and pair-fed birds. Digestibility of N, both apparent and ileal, was substantially lower with SSM diet than with the control diet. Each of the treatments induced enlargement of the pancreas ( $\mathrm{g}$ pancreas/ $\mathrm{kg}$ live weight) when compared with $\mathrm{ad}$ lib. birds. There was no difference between the relative liver weights of SSM and ad lib. birds; however, pair-fed and young birds had comparatively bigger livers. In pair-fed birds the trypsinogen activity of pancreatic tissue (U/g pancreatic tissue) was significantly depressed but there was a significant elevation in trypsinogen (U/kg live weight) activity in SSM birds; again pair-fed birds exhibited the lowest value for this variable. Compared with control birds all the other treatments resulted in significant depression of $\alpha$-amylase (EC 3.2.1.1) activity in pancreatic tissue $(\mathrm{U} / \mathrm{g})$ and jejunal digesta $(\mathrm{U} / \mathrm{g})$, but because of pancreatic enlargement $\alpha$-amylase activity per kg live weight was significantly lower only in SSM birds. The activity of trypsin (EC 3.4.21 .4) in jejunal digesta was very low in SSM birds, but it was slightly higher in the young birds. Dipeptidase (EC 3.4.13.11) and disaccharidases in duodenal and jejunal mucosa were markedly depressed by the diet containing salseed meal, with the exception of maltase (EC 3.2.1.20) which was unaffected in jejunal mucosa. Enterokinase $(E C 3.4 .21 .9)$ activity was not inhibited by the presence of tannins in the diet, rather it increased in the duodenal mucosa of SSM birds.
\end{abstract}

Tannins: Digestive enzymes: Pancreas: Feed intake: Live weight: Salseed meal

The antinutritional properties of tannins are well documented from numerous in vitro (Schaffert et al. 1974; Ramachandra et al. 1977; Chibber et al. 1980; Horigome et al. 1988; Garrido et al. 1989), and in vivo (Cousins et al. 1981; Horigome et al. 1988; Ahmed et al. 1991) studies, which showed reduced digestibility of protein in diets containing tannins. Many experiments have shown that tannins in the diet result in reduced weight gain and poor feed efficiencies in chicks (Armstrong et al. 1974; Ahmed et al. 1991), rats (Featherston \& Rogler, 1975; Elkin et al. 1990; Mole et al. 1990) and pigs (Pathak \& Ranjahan, 1973; Cousins et al. 1981; Mitaru et al. 1984).

Tannins may form stable complexes with dietary protein thereby reducing its digestibility (Oh et al. 1980; Hagerman \& Klucher, 1986; Marquardt, 1989). They may also form tannin-enzyme complexes with digestive enzymes (Griffiths, 1979) and inhibit enzyme 
activity. Condensed tannins have been shown to inhibit in vitro activity of digestive enzymes including trypsin (EC 3.4.21.4), $\alpha$-amylase $(E C 3.2 .1 .1)$ and lipase (EC 3.1.1.3) (Tamir \& Alumot, 1969; Griffiths, 1981; Singh, 1984). Results from in vivo studies showed lower activities of trypsin and $\alpha$-amylase in the digesta from various parts of the digestive tract of animals fed on tannin-containing diets (Horigome et al. 1988; Ahmed et al. 1991; Longstaff \& McNab, 1991), but increased activities of lipase in digesta have been reported (Griffiths \& Moseley, 1980; Horigome et al. 1988; Longstaff \& McNab, 1991).

In a recent study Ahmed et al. (1991) found that $\mathrm{N}$ digestibility and feed intake declined as the proportion of salseed (Shorea robusta) meal tannin in the diet of male broiler chicks was increased. A significant increase in the relative weight of the pancreas has been reported in birds fed on diets containing tannin (Ahmed, 1991; Ahmed et al. 1991) and trypsin inhibitor (TI) (Gertler \& Nitsan, 1970; Rubio et al. 1989). Thus, pancreatic hypertrophy in birds has been associated with the presence of tannin or TI in the diet. However, birds fed on tannin-containing diets eat less feed and are lighter in weight than normally-fed birds. Because it is not known whether birds fed on tannin-free diets at a lower feed intake or fed to a lighter body weight would have an enlarged pancreas, the contribution of the pancreas may be overestimated. The present study was planned to ascertain whether restriction of feed intake to the same level as that of birds receiving tannin, or the use of younger birds with smaller body weights, would show effects, similar to those associated with dietary tannins, on pancreas weight and on activities of enzymes in the pancreas and the small intestine. The experiment was also used to examine effects on the digestibility of $\mathrm{N}$ and live-weight gain. To provide points of reference to the effects of dietary tannins, groups of birds were fed ad lib. on either a tannin-containing diet (SSM) or a tannin-free diet (CONTROL). The effect of lower feed intake was studied by pair-feeding a group of birds (pair-fed) with the tannin-free diet at the same level as the SSM birds. The effect of body weight was studied in a group of birds (young) by feeding them ad lib. on the control diet until they achieved approximately the same body weight as the SSM group. For the present experiment salseed meal from south-east India (Grosvenor Grain and Feed Co. Ltd, Liverpool), the residue of sal tree fruit after the extraction of oil, was used as a source of tannin.

\section{MATERIALS AND METHODS}

\section{Animals}

Sixty 1-d-old male broiler (Cobb) chicks were purchased from a commercial hatchery and were reared in a group for 2 weeks, under the same conditions of space, light, temperature and humidity. They were fed on a commercial broiler starter mash up to 2 weeks of age. At the end of this adaptation period the birds were weighed individually and forty-eight birds of middle weight-range (335-380 g) were selected and transferred to individual battery cages to be used as experimental animals. Each cage was supplied with an individual drinker, a feeder and a tray for excreta collection. The caged birds were allocated to three groups (SSM, ad lib. and pair-fed), sixteen birds in each group and were fed on the experimental diets.

At the end of week 3 another group of twenty broiler chicks of the same breed and sex were obtained from the same hatchery and were reared under the same management conditions for 2 weeks. At the end of the second week these chicks were weighed and a group of sixteen chicks (young) having approximately the same weight as those of the first forty-eight chicks were randomly allocated to individual battery cages and fed on the experimental diet. 
Table 1. Composition of the experimental diets

\begin{tabular}{|c|c|c|}
\hline Diet... & SSM & CONTROL \\
\hline \multicolumn{3}{|l|}{ Ingredients $(\mathrm{g} / \mathrm{kg})$} \\
\hline Salseed meal & 507.5 & - \\
\hline Barley & - & 507.5 \\
\hline Maize & $171 \cdot 0$ & $199 \cdot 0$ \\
\hline Soya-bean meal & $200 \cdot 0$ & $200 \cdot 0$ \\
\hline Fish meal & $83 \cdot 0$ & $61 \cdot 5$ \\
\hline Vegetable oil & 38.5 & $32 \cdot 0$ \\
\hline \multicolumn{3}{|l|}{ Chemical composition (calculated) } \\
\hline Crude protein $(\mathrm{N} \times 6.25 ; \mathrm{g} / \mathrm{kg})$ & $204 \cdot 9$ & $204 \cdot 9$ \\
\hline Metabolizable energy $(\mathrm{MJ} / \mathrm{kg})$ & $12 \cdot 2$ & $12 \cdot 2$ \\
\hline Tannins $(\mathrm{g} / \mathrm{kg})$ & $41 \cdot 0$ & - \\
\hline
\end{tabular}

\section{Diets, groups and their feeding plan}

Two isonitrogenous $(32.8 \mathrm{mg} \mathrm{N} / \mathrm{g}$ dry matter (DM)) and isoenergetic (12.2 MJ/kg DM) rations (Table 1) containing $0.5 \mathrm{~g} \mathrm{Cr}_{2} \mathrm{O}_{3} / \mathrm{kg}$ diet as an indigestible marker were formulated, one containing salseed meal (SSM) and the other containing barley (CONTROL) as a major energy source. The salseed meal used in the SSM diet was analysed for condensed tannin $(12.4 \mathrm{~g} / \mathrm{kg}$ ) using the vanillin reaction (Price et al. 1978) and for hydrolysable tannin $(68.3 \mathrm{~g} / \mathrm{kg}$ ) using dye-labelled protein (Asquith \& Butler, 1985). The groups and their feeding plan after the adaptation period were as follows: (1) SSM, fed ad lib. on SSM diet during weeks 3, 5 and 6; (2) ad lib., fed ad lib. on CONTROL diet during weeks 3,5 and 6; (3) pair-fed, fed on CONTROL diet at same intake as SSM birds during weeks 3, 5, and 6; (4) young, fed ad lib. on CONTROL diet to age $25 \mathrm{~d}$.

Each bird in the pair-fed groups was matched with one of similar body weight in the SSM group for the purpose of determining the amounts of feed offered. The quantity of feed offered each day to each pair-fed bird was the same as the quantity consumed by its pair in the SSM group. The birds in the young group were started on the trial 3 weeks after the other birds and were fed ad lib. until the group mean live weight was the same as that of the SSM group at slaughter.

\section{Nitrogen digestibility and retention}

Digestibility of $\mathrm{N}$ was determined only for birds in the SSM, ad lib. and pair-fed groups. For the first $7 \mathrm{~d}$ of the experimental period (week 3 ) no excreta collection was made while the $\mathrm{Cr}_{2} \mathrm{O}_{3}$ passage was becoming stabilized (Kotb \& Luckly, 1972) in faeces. During the digestibility collection period (week 4) the amount of feed offered to all groups was the same. The amount offered was limited to the amount which the SSM birds would consume. Excreta collections, which started on the 8th experimental day, were made six times daily over twelve consecutive hours, for a period of $7 \mathrm{~d}$. The times of the $12 \mathrm{~h}$ collection periods were changed, starting $2 \mathrm{~h}$ later each day, so that the collections were representative of fresh excreta from the equivalent of four full days. Excreta was immediately frozen after each $2 \mathrm{~h}$ collection. At the end of the $7 \mathrm{~d}$ collection period the excreta was freeze-dried, ground and stored in air-tight plastic containers at $4^{\circ}$ until they were analysed for total $\mathrm{N}, \mathrm{Cr}_{2} \mathrm{O}_{3}$, uric acid and $\mathrm{NH}_{3}-\mathrm{N}$ as described by Ahmed et al. (1991). $\mathrm{N}$ digestibility and retention were calculated by the method of Terpstra \& De Hart (1974). Ileal digestibility of $N$ was determined in the digesta collected from the terminal ileum when the birds were killed. 


\section{Collection of digesta, mucosa and pancreas samples}

At the end of the experiment each bird was anaesthetized and killed by cervical dislocation and the digestive tract and pancreas were excised. Each pancreas was weighed, immediately frozen in liquid $\mathrm{N}_{2}$ and stored at $-70^{\circ}$. Sections $(150 \mathrm{~mm})$ of distal duodenum, jejunum and terminal ileum were taken. Digesta were collected from the ileal and jejunal sections and stored at $-20^{\circ}$. Remaining digesta from the duodenal section and digesta from a separate jejunal section were washed out carefully with normal saline $(9 \mathrm{~g} \mathrm{NaCl} / 1)$ solution. The sections were then cut open on an ice-cooled sheet of glass and the mucosa was scraped from the gut section with a microscope slide and stored at $-20^{\circ}$.

\section{Determination of enzyme activities}

Jejunal digesta $(0 \cdot 8-1.0 \mathrm{~g})$ was homogenized in $15 \mathrm{ml}$ buffer solution $(0.04 \mathrm{M}$-Tris, $0.01 \mathrm{M}$ $\mathrm{CaCl}_{2}, \mathrm{pH} \mathrm{8.1)}$ and the homogenates were centrifuged at $35000 \mathrm{~g}$ for $20 \mathrm{~min}$ at $4^{\circ}$. Supernatant fractions were assayed for trypsin activity (Liu \& Markakis, 1989) using sodium benzoyl-DL-arginine $p$-nitroanilide as substrate, and for $\alpha$-amylase using maltotetraose as the substrate (clinical analyzer MA-KIT, Art. 071094 6, Roche).

Each pancreas was thawed, sliced into smaller pieces and homogenized in $30 \mathrm{ml}$ buffer solution (Tris $50 \mathrm{~mm}, \mathrm{KCl} 0.154 \mathrm{M}, \mathrm{pH} \mathrm{7.5}$ ), centrifuged at $35000 \mathrm{~g}$ for $20 \mathrm{~min}$ at $4^{\circ}$. Trypsinogen in a portion of the supernatant fraction was activated by incubating with enterokinase (EC 3.4.21.9) at $37^{\circ}$ for $1 \mathrm{~h}$ (Gertler \& Nitsan, 1970) and then activity of trypsin was determined. $\alpha$-amylase activity was determined in a second portion of supernatant fraction.

Mucosal samples were thawed and approximately $1 \mathrm{~g}$ mucosa was accurately weighed and homogenized in $25 \mathrm{ml}$ ice-cold glycerol $(140 \mathrm{ml} / 1)$. The homogenates were centrifuged at $35000 \mathrm{~g}$ for $20 \mathrm{~min}$ at $4^{\circ}$. The supernatant fraction was diluted with the homogenizing solution and analysed for dipeptidase (EC 3.4.13.11) activity by the method based on Nicholson \& Kim (1975), modified by Collington (1990). Activities of the disaccharidases sucrase $(E C 3.2 .1 .48)$ and maltase $(E C 3.2 .1 .20)$ were determined by the methods described by Dahlquist (1968), terminating the reaction in a boiling water-bath and substituting ABTS for $o$-dianisidine as the chromogen. Enterokinase (EC 3.4.21.9) activity was determined by the method used by Ahmed (1991). Protein contents in the mucosal supernatant fraction were determined by a protein-dye-binding method (Bradford, 1976).

\section{Statistical analysis}

Analysis of variance was carried out to detect differences between treatments and the means were compared using Duncan's multiple-range test.

RESULTS

In the following commentary on the results of the experiment the mean values for the ad $l i b$. birds have been taken as reference points for comparison of the other treatments. Not unexpectedly, the pair-fed birds, whose feed allocation was restricted, grew more slowly (Table 2). However, the SSM birds which consumed the same weight of feed grew still more slowly. Ad lib. birds utilized their diet more efficiently than both the SSM and the pair-fed birds. Digestibility of N, both apparent and ileal, was substantially lower with the SSM diet than that of the CONTROL diet. Whilst there was no difference between the relative liver weights of SSM and ad lib. birds, those whose diets were restricted (pair-fed) and those which were younger (young) had comparatively bigger livers (Table 3). Each of the 
Table 2. Final live weight, live-weight gain, feed conversion efficiency, apparent and ileal $N$ digestibility and $N$ retention in birds fed ad lib. on a tannin-containing diet or on a tannin-free diet under different feeding regimens*

(Mean values with their standard errors)

\begin{tabular}{|c|c|c|c|c|c|c|c|c|}
\hline \multirow{3}{*}{$\begin{array}{l}\text { Diets... } \\
\text { Groups... }\end{array}$} & \multirow{2}{*}{\multicolumn{2}{|c|}{$\begin{array}{l}\text { SSM } \\
\text { SSM }\end{array}$}} & \multicolumn{6}{|c|}{ CONTROL } \\
\hline & & & \multicolumn{2}{|c|}{ ad lib. } & \multicolumn{2}{|c|}{ Pair-fed } & \multicolumn{2}{|c|}{ Young } \\
\hline & Mean & $\mathrm{SE}$ & Mean & $\mathrm{SE}$ & Mean & $\mathrm{SE}$ & Mean & $\mathrm{SE}$ \\
\hline Period of feeding (d) & 28 & - & 28 & - & 28 & -. & 10 & - \\
\hline Final live wt $(\mathrm{g})$ & 850 & - & 1903 & - & 1265 & - & 859 & - \\
\hline Live-wt gain ( $\mathrm{g}$ in $28 \mathrm{~d}$ ) & $496^{\mathrm{a}}$ & 36 & $1549^{c}$ & 21 & $911^{\mathrm{b}}$ & 41 & - & - \\
\hline $\begin{array}{l}\text { Feed conversion efficiency } \\
\text { (g gain/g feed intake) }\end{array}$ & $0 \cdot 25^{\mathrm{a}}$ & 0.01 & $0.51^{\mathrm{c}}$ & 0.007 & $0.47^{b}$ & 0.008 & - & - \\
\hline $\begin{array}{l}\text { Apparent digestibility } \\
\text { of } \mathrm{N}\end{array}$ & $0 \cdot 43^{\mathrm{a}}$ & 009 & $0 \cdot 78^{\mathrm{b}}$ & 0.04 & $0-78^{b}$ & 0.07 & - & - \\
\hline $\mathrm{N}$ retention $(\mathrm{g} / \mathrm{kg})$ & $27 \cdot 25^{\mathrm{a}}$ & 0.63 & $60 \cdot 09^{b}$ & 0.98 & $60 \cdot 33^{\mathrm{b}}$ & $1 \cdot 23$ & - & - \\
\hline lleal digestibility of $\mathrm{N}$ & $0 \cdot 50^{\mathrm{a}}$ & $0 \cdot 20$ & $0 \cdot 84^{\mathrm{b}}$ & $0 \cdot 08$ & $0 \cdot 84^{\mathrm{b}}$ & $0 \cdot 61$ & $0 \cdot 84^{b}$ & 0.08 \\
\hline
\end{tabular}

a, b, c Values within the same row with unlike superscript letters were significantly different $(P<0 \cdot 05)$.

* For details of diets and treatment groups, see Table 1 and p. 703.

Table 3. Relative liver weight, relative pancreas weight and enzyme activities (Units $\times 10^{-2}$ ) in the pancreatic tissue of birds fed ad lib. on a tannin-containing diet or on a tannin-free diet under different feeding regimens*

(Mean values with their standard errors)

\begin{tabular}{|c|c|c|c|c|c|c|c|c|}
\hline \multirow{3}{*}{$\begin{array}{l}\text { Diets... } \\
\text { Groups... }\end{array}$} & \multirow{2}{*}{\multicolumn{2}{|c|}{$\begin{array}{l}\text { SSM } \\
\text { SSM }\end{array}$}} & \multicolumn{6}{|c|}{ CONTROL } \\
\hline & & & \multicolumn{2}{|c|}{ ad lib. } & \multicolumn{2}{|c|}{ Pair-fed } & \multicolumn{2}{|c|}{ Young } \\
\hline & Mean & $\mathrm{SE}$ & Mean & $\mathrm{SE}$ & Mean & se & Mean & SE \\
\hline Liver wt (g/kg live wt) & $21 \cdot 7^{a}$ & 0.57 & $21 \cdot 1^{\mathrm{a}}$ & 0.67 & $24 \cdot 4^{b}$ & $0 \cdot 86$ & $27 \cdot 4^{c}$ & 1.0 \\
\hline Pancreas wt (g/kg live wt) & $3 \cdot 38^{\mathrm{a}}$ & $0 \cdot 16$ & $1.99^{\mathrm{d}}$ & 0.06 & $2 \cdot 30^{\mathrm{c}}$ & 0.06 & $2 \cdot 92^{\mathrm{b}}$ & 0.05 \\
\hline \multicolumn{9}{|l|}{ Trypsinogen $(E C 3.4 .21 .4)$} \\
\hline Units/g pancreatic tissue & $169^{a}$ & 15 & $165^{\varkappa}$ & 16 & $119^{\mathrm{b}}$ & 13 & $148^{a b}$ & 14 \\
\hline Units $/ \mathrm{kg}$ live wt & $521^{a}$ & 56 & $307^{\mathrm{bc}}$ & 28 & $256^{\mathrm{c}}$ & 29 & $427^{\mathrm{ab}}$ & 42 \\
\hline \multicolumn{9}{|l|}{$\alpha$-Amylase $(E C 3.2 .1 .1)$} \\
\hline Units/g pancreatic tissue & $61^{a}$ & 6 & $177^{c}$ & 9 & $138^{\mathrm{b}}$ & 11 & $133^{b}$ & 9 \\
\hline Units $/ \mathrm{kg}$ live wt & $183^{\mathrm{a}}$ & 17 & $330^{\mathrm{bc}}$ & 19 & $301^{\mathrm{b}}$ & 28 & $385^{\mathrm{c}}$ & 30 \\
\hline
\end{tabular}

a. b. : Values within the same row with unlike superscript letters were significantly different $(P<0 \cdot 05)$.

* For details of diets and treatment groups, see Table 1 and p. 703 .

treatments induced enlargement of the pancreas compared with the ad lib. birds. Only in pair-fed birds was trypsinogen activity of pancreatic tissue (U/g pancreatic tissue) significantly depressed. However, when both the weight of the pancreas and the body weight of the bird were taken into consideration there was a significant elevation in trypsinogen (U/ kg live-weight) activity in SSM birds; pair-fed birds exhibited the lowest value for this variable. Each of the treatments resulted in significant depression of $\alpha$ amylase activity in pancreatic tissue (U/g pancreatic tissue), but when pancreas weight and 
Table 4. Enzyme activities in the jejunal digesta of birds fed ad lib. on a tannincontaining diet or on a tannin-free diet under different feeding regimens*

(Mean values with their standard errors)

\begin{tabular}{|c|c|c|c|c|c|c|c|c|}
\hline \multirow{3}{*}{$\begin{array}{l}\text { Diets... } \\
\text { Groups... }\end{array}$} & \multirow{2}{*}{\multicolumn{2}{|c|}{$\begin{array}{l}\text { SSM } \\
\text { SSM }\end{array}$}} & \multicolumn{6}{|c|}{ CONTROL } \\
\hline & & & \multicolumn{2}{|c|}{ ad lib. } & \multicolumn{2}{|c|}{ Pair-fed } & \multicolumn{2}{|c|}{ Young } \\
\hline & Mean & $\mathrm{SE}$ & Mean & $\mathrm{SE}$ & Mean & SE & Mean & $\mathrm{SE}$ \\
\hline \multicolumn{9}{|l|}{ Trypsin (EC 3.4.21.4) } \\
\hline Units/g wet chyme & $1525^{a}$ & 107 & $2853^{\mathrm{b}}$ & 138 & $2550^{\mathrm{b}}$ & 143 & $3471^{\mathrm{c}}$ & 215 \\
\hline Units/g dry chyme & $3436^{\mathrm{a}}$ & 285 & $7265^{b c}$ & 571 & $6174^{\mathrm{b}}$ & 309 & $8681^{c}$ & 430 \\
\hline \multicolumn{9}{|l|}{$\alpha$-Amylase $(E C 3.2,1,1)$} \\
\hline Units/g wet chyme & $66^{\mathrm{a}}$ & 9 & $546^{\mathrm{c}}$ & 31 & $440^{\mathrm{b}}$ & 42 & $373^{b}$ & 35 \\
\hline Units/g dry chyme & $148^{\mathrm{a}}$ & 20 & $1373^{c}$ & 98 & $1074^{\mathrm{b}}$ & 102 & $939^{\mathrm{b}}$ & 85 \\
\hline
\end{tabular}

a, b, c Values within the same row with unlike superscript letters were significantly different $(P<0 \cdot 05)$.

* For details of diets and treatment groups, see Table 1 and p. 703.

Table 5. Enzyme activities (Units/g mucosa) in the duodenal mucosa of birds fed ad lib. on a tannin-containing diet or on a tannin-free diet under different feeding regimens*

(Mean values with their standard errors)

\begin{tabular}{|c|c|c|c|c|c|c|c|c|}
\hline \multirow{3}{*}{$\begin{array}{l}\text { Diets... } \\
\text { Groups... }\end{array}$} & \multirow{2}{*}{\multicolumn{2}{|c|}{$\begin{array}{l}\text { SSM } \\
\text { SSM }\end{array}$}} & \multicolumn{6}{|c|}{ CONTROL } \\
\hline & & & \multicolumn{2}{|c|}{ ad lib. } & \multicolumn{2}{|c|}{ Pair-fed } & \multicolumn{2}{|c|}{ Young } \\
\hline & Mean & $\mathrm{SE}$ & Mean & $\mathrm{SE}$ & Mean & se & Mean & $\mathrm{SE}$ \\
\hline Dipeptidase ( $E C$ 3.4.13.11) & $111^{a}$ & 6 & $275^{\mathrm{c}}$ & 12 & $233^{\mathrm{b}}$ & 11 & $221^{\mathrm{b}}$ & 13 \\
\hline Sucrase $(E C 3.2 .1 .48)$ & $0.23^{\mathrm{a}}$ & 0.01 & $0.41^{\complement}$ & 0.02 & $0.37^{\mathrm{bc}}$ & $0 \cdot 01$ & $0.33^{\mathrm{b}}$ & 0.02 \\
\hline Maltase $(E C 3.2 .1 .20)$ & $162^{\mathrm{a}}$ & 0.60 & $22 \cdot 9^{\circ}$ & 1.62 & $20 \cdot 5^{\text {he }}$ & 0.87 & $18 \cdot 8^{\mathrm{ab}}$ & 1.32 \\
\hline Enterokinase $(E C$ 3.4.21.9) & $572^{\mathrm{a}}$ & 17 & $432^{b}$ & 21 & $378^{c}$ & 15 & $325^{\mathrm{d}}$ & 17 \\
\hline
\end{tabular}

$a_{r}, c, c$ Values within the same row with unlike superscript letters were significantly different $(P<0 \cdot 05)$.

* For details of diets and treatment groups, see Table 1 and p. 703.

body weight were taken into consideration the total pancreatic $\alpha$-amylase activity was significantly lower only in SSM birds.

In contrast to the levels of pancreatic trypsinogen, which exhibited an increased activity in response to the SSM diet, the activity of trypsin in jejunal digesta was severely depressed in SSM birds (Table 4). In the young birds trypsin activity in digesta was slightly higher. On the other hand the activities of $\alpha$-amylase in the digesta followed a trend similar to that in the pancreatic tissue.

Dipeptidase and the disaccharidases in duodenal mucosa (Table 5) were markedly depressed in SSM birds but only slightly lower in pair-fed and young birds. In the jejunal mucosa (Table 6), with the exception of maltase which was unaffected, the enzymes showed a similar trend but differences between treatments were smaller. Comparing the activities of the mucosal enzymes of the duodenum and the jejunum, dipeptidase was higher in the duodenum whilst the disaccharidases were present at higher activities in the jejunum. Enterokinase activity was not inhibited by the presence of tannins in the diet, instead it increased significantly in the duodenal mucosa. 
Table 6. Enzyme activities (Units/g mucosa) in the jejunal mucosa of birds fed ad lib. on a tannin-containing diet or on a tannin-free diet under different feeding regimens*

(Mean values with their standard errors)

\begin{tabular}{|c|c|c|c|c|c|c|c|c|}
\hline \multirow{3}{*}{$\begin{array}{l}\text { Diets ... } \\
\text { Groups ... }\end{array}$} & \multirow{2}{*}{\multicolumn{2}{|c|}{$\begin{array}{l}\text { SSM } \\
\text { SSM }\end{array}$}} & \multicolumn{6}{|c|}{ CONTROL } \\
\hline & & & \multicolumn{2}{|c|}{$a d l i b}$. & \multicolumn{2}{|c|}{ Pair-fed } & \multicolumn{2}{|c|}{ Young } \\
\hline & Mean & $\mathrm{SE}$ & Mean & $\mathrm{SE}$ & Mean & $\mathrm{SE}$ & Mean & $\mathrm{SF}$ \\
\hline Dipeptidase $(E C 3,4.13 .11)$ & $81^{\mathrm{a}}$ & 5 & $187^{\circ}$ & 17 & $134^{\mathrm{b}}$ & 11 & $133^{\mathrm{b}}$ & 10 \\
\hline Sucrase $(E C 3.2 .1 .48)$ & $0 \cdot 60^{\mathrm{a}}$ & 0.03 & $0.73^{\mathrm{b}}$ & 0.04 & $0.69^{a b}$ & 0.04 & $0.66^{\mathrm{ab}}$ & 0.04 \\
\hline Maltase $(E C 3.2 .1 .20)$ & $44-3^{\mathrm{a}}$ & $2 \cdot 7$ & $46 \cdot 5^{\mathrm{a}}$ & 2.7 & $46 \cdot 0^{\mathrm{a}}$ & $2 \cdot 8$ & $44 \cdot 0^{\mathrm{a}}$ & 30 \\
\hline Enterokinase $(E C 3.4 .21 .9)$ & $220^{\mathrm{a}}$ & 8 & $233^{\mathrm{a}}$ & 8 & $197^{\mathrm{h}}$ & 8 & $151^{\mathrm{c}}$ & 5 \\
\hline
\end{tabular}

a. b. . Values within the same row with unlike superscript letters were significantly different $(P<0.05)$.

* For details of diets and treatment groups, see Table 1 and p. 703.

\section{DISCUSSION}

Pancreatic hypertrophy in birds fed on diets containing TI (Levison et al. 1979), lectin (Abbey et al. 1979; Grant et al. 1987) or tannin (Ahmed et al. 1991) has been tacitly ascribed in its entirety to the direct effect of the antinutritional substance. However, the results of the present experiment show that merely limiting the feed intake of birds fed on a tannin-free diet can result in a higher relative pancreas weight compared with those which are fed $a d l i b$. on the same diet. Also in younger, lighter birds which were fed ad lib. on tannin-free diet the pancreas constituted a higher proportion of live weight. The number of treatments applied in the present experiment is not sufficient to justify an unequivocal claim of a relationship between live weight and relative pancreas weight. Nevertheless, the fact that the regression of relative pancreas weight $(x) v$. live weight $(y)$ for the birds fed on the tannin-free diet $\left(x=3.37-0.677 y ; R^{2} 0.678 ; P<0.001\right)$ was statistically significant does give strong support for the notion that part of the pancreatic hypertrophy associated with dietary tannin is due to the smaller size of the bird. In the present experiment the lower live weights of birds fed on the tannin-free diet were obtained by two different means, namely limitation of feed intake and age; this introduced unnecessarily an additional variable, age. With hindsight it can be seen that a better approach would have been to control live weight by imposing several different limits on feed intake rather than by using birds of different ages. The clearly higher relative weight of the pancreas in the birds fed on the tannin-containing diet compared with all the other groups demonstrates that, in addition to any indirect effect of tannin by way of live-weight limitation, tannin also exerts a separate effect on the pancreas. The means which were used to limit live weights of the birds fed on the tannin-free diet also lowered the contents of trypsinogen and $\alpha$-amylase in the pancreatic tissue; in the case of trypsinogen this effect is the opposite of the effect of the tannin on trypsinogen. The depression of pancreatic tissue $\alpha$-amylase activity in the birds fed on the SSM diet evident in the present experiment was not seen in that of Ahmed et al. (1991), but Ahmed (1991) did obtain similar responses in later experiments.

The activities of trypsin and $\alpha$-amylase in the jejunum of the groups fed on tannin-free diets follow reasonably closely the pattern of the trypsinogen and $\alpha$-amylase in the pancreas when expressed on a live-weight basis. In the birds fed on the tannin-containing diet the depression in the activities of both of these enzymes is severe, far exceeding the effects of lighter body weight associated with feed restriction or age. The effect of the tannincontaining diet on the activities of trypsin and $\alpha$-amylase in the jejunum is more than might 
be expected from the amounts of enzyme or zymogen in the pancreas. Ahmed (1991) has shown that addition of polyvinyl-polypyrrolidone, which is known to bind strongly with tannin, to jejunal digesta of birds fed on tannin-containing diets increases the activities of trypsin and $\alpha$-amylase. These findings suggest that the major effect of the tannin on these enzymes is through direct tannin-enzyme interaction in the intestine (Griffiths, 1979). A further influence on the activity of trypsin in the intestine is the activity of enterokinase. However, since the enterokinase appears to have been higher in the birds fed on the tannincontaining diet, it is unlikely that the lower tryptic activity of intestinal digesta results from depressed capacity for activation of trypsinogen.

Although the results of the present experiment strongly implicate inactivation of intestinal digestive enzymes in the reduction of protein digestion by the presence of tannins in the diets, the relative contribution of tannin-enzyme and tannin-dietary protein interaction will only be decided by studies which identify the contribution of endogenous protein to faecal $\mathrm{N}$ (de Lange et al. 1989, 1990).

\section{REFERENCES}

Abbey, B. W., Norton, G. \& Neale, R. J. (1979). Effect of dietary proteinase inhibitors from field bean (Vicia faba L.) and field bean meal on pancreatic function in rats. British Journal of Nutrition 41, 39-45.

Ahmed, A. E. (1991). Anti-nutritional role of dietary tannins in the domestic fowl (Gallus domesticus). PhD Thesis, University of Newcastle Upon Tyne.

Ahmed, A. E., Smithard, R. \& Ellis, M. (1991). Activities of enzymes of the pancreas, and the lumen and mucosa of the small intestine in growing broiler cockerels fed on tannin-containing diets. British Journal of Nutrition 65, 189-197.

Armstrong, W. D., Featherston, W. R. \& Rogler, J. C. (1974). Effects of bird resistant sorghum grain and various commercial tannins on chick performance. Poultry Science 53, 2137-2142.

Asquith, T. N. \& Butler, L. G. (1985). Use of dye-labelled protein as a spectrophotometric assay for protein precipitants such as tannin. Journal of Chemical Ecology 11, 1535-1544.

Bradford, M. M. (1976). A rapid and sensitive method for the quantitation of microgram quantities of protein utilizing the principle of protein-dye binding. Analytical Biochemistry 72, 248-254.

Chibber, B. A. K., Mertz, E. T. \& Axtell, J. D. (1980). In vitro digestibility of high-tannin sorghum at different stages of dehulling. Journal of Agricultural and Food Chemistry 28, 160-161.

Collington, G. K. (1990). Effects of probiotics preparation on porcine small intestinal function. PhD Thesis, University of Newcastle Upon Tyne.

Cousins, B. W., Tanksley, T. D., Knabe, D. A. \& Zebrowska, T. (1981). Nutrient digestibility and performance of pigs fed sorghums varying in tannin concentration. Journal of Animal Science 53, 1524-1537.

Dahlquist, A. (1968). Assay of intestinal disaccharidase. Analytical Biochemistry 22, 99-107.

de Lange, C. F. M., Sauer, W. C., Mosenthin, R. \& Souffrant, W. B. (1989). The effect of feeding different proteinfree diets on the recovery and amino acid composition of endogenous protein collected from the distal ileum and faeces in pigs. Journal of Animal Science 67, 746-754.

de Lange, C. F. M., Souffrant, W. B. \& Sauer, W. C. (1990). Real ileal protein and amino acid digestibilities in feedstuff for growing pigs as determined with the ${ }^{15} \mathrm{~N}$-isotope dilution technique. Journal of Animal Science 68 , $409-418$

Elkin, R. G., Rogler, J. C. \& Sullivan, T. W. (1990). Comparative effects of dietary tannins in ducks, chicks and rats. Poultry Science 69, 1685-1693.

Featherston, W, R. \& Rogler, J. C. (1975). Influence of tannins on the utilization of sorghum grains in rats and chicks. Nutrition Reports International 11, 491-497.

Garrido, A., Cabrera, A., Comez, A. \& Guerrero, J. E. (1989). Relationship between tannin content and 'in vitro' nutritive value in seeds of 24 strains of Vicia faba L. Proceedings of the first International Workshop on Antinutritional Factors (ANF) in Legume Seeds, pp. 160-163 [J. Huisman, T. F. B., van der Poel and I. E. Liener, editors]. Wageningen, Netherlands: Pudoc Wageningen.

Gertler, A. \& Nitsan, Z. (1970). The effect of trypsin inhibitors on pancreatopeptidase E, trypsin, chymotrypsin and amylase in the pancreas and intestinal tract of chicks receiving raw and heated soya beans diets. British Journal of Nutrition 24, 893-904.

Grant, G., Wat, W. B., Stewart, J. C. S. \& Pusztai, A. (1987). Effect of dietary soya bean (Glycine max) lectin and trypsin inhibitors upon the pancreas of the rat. Medical Science Research 15, 1197-1198.

Griffiths, D. W. (1979). The inhibition of digestive enzymes by extracts of field beans (Vicia faba). Journal of the Science of Food and Agriculture 30, 458462.

Griffiths, D. W. (1981). The polyphenolic contents and enzyme inhibiting activity of testas from beans ( Vicia faba) and pea (Pisum spp.) varieties. Journal of the Science of Food and Agriculture 32, 797-804. 
Griffiths, D. W. \& Moseley, G. (1980). The effect of diets containing field beans of high and low polyphenolic content on the activity of digestive enzymes in the intestines of rats. Journal of the Science of Food and Agriculture 31, 255-259.

Hagerman, A. E. \& Klucher, K. M. (1986). Tannin protein interaction. In Flavonoids in Biology and Medicine. Biochemical, Pharmacological and Structure-Activity Relationships, pp. 67-76 [J. Harborne and E. Middleton, editors]. New York: Alan R. Liss.

Horigome, T., Kumar, R. \& Okamoto, K. (1988). Effects of condensed tannins prepared from leaves of fodder plants on digestive enzymes in vitro and in the intestine of rats. British Journal of Nutrition 60, 275-285.

Kotb, A. R. \& Luckly, T. D. (1972). Markers in nutrition. Nutrition Abstracts and Reviews 42, 813-845.

Levison, D. A., Morgan, R. G. H., Brimacombe, J. S., Hopwood, D., Coghill, G. \& Wormsley, K. G. (1979). Carcinogenic effects of di-(2-hydroxypropyl)-nitrosamine (DHPN) in male Wistar rats: promotion of pancreatic cancer by a raw soya flour diet. Scandinavian Journal of Gastroenterology 14, 217-224.

Liu, K. \& Markakis, P. (1989). An improved colorimetric method for determining antitryptic activity in soybean products. Cereal Chemistry 66, 415-422.

Longstaff, M. \& McNab, J. M. (1991). The inhibitory effects of hull polysaccharides and tannins of field beans (Vicia faba L.) on the digestion of amino acids, starch and lipid and on digestive enzyme activities in young chicks. British Journal of Nutrition 65, 199-216.

Marquardt, R. R. (1989). Dietary effects of tannins vicine and covicine. Proceedings of the first International Workshop on Antinutritional factors $(A N F)$ in Legume Seeds, pp. 141-155 [J. Huisman, T. F. B. van der Poel and I. E. Liener, editors]. Wageningen, Netherlands: Pudoc Wageningen.

Mitaru, B. N., Reichert, R. D. \& Blair, R. (1984). The binding of dietary protein by sorghum tannins in the digestive tract of pigs. Journal of Nutrition 114, 1787-1796.

Mole, S., Rogler, J. C., Morell, C. J. \& Butler, L. G. (1990). Herbivore growth reduction by tannins: use of waldbauer ratio techniques and manipulation of salivary protein production to elucidate mechanism of action. Biochemical Systematics and Ecology 18, 183-197.

Nicholson, J. A. \& Kim, Y.S. (1975). A one step L-amino acid oxidase assay for intestinal peptide hydrolysis activity. Analytical Biochemistry 63, 100-117.

Oh, H. I., Hoff, J. E., Armstrong, G. S. \& Haff, L. A. (1980). Hydrophobic interaction in tannin-protein complexes. Journal of Agricultural and Food Chemistry 28, 394-398.

Pathak, N. N. \& Ranjahan, S. K. (1973). Nutritional studies with salseed-meal as a component of finisher rations in the Large White Yorkshire pigs. Indian Journal of Animal Science 43, 424 427.

Price, M. L., Van Scoyoc, S. \& Butler, L. G. (1978). A critical evaluation of the Vanillin reaction as an assay for tannin in sorghum grain. Journal of Agricultural and Food Chemistry 26, $1214-1218$.

Ramachandra, G., Virupaksha, T. K. \& Swamy, S. K. (1977). Relationship between tannin levels and in vitro protein digestibility in finger millet (Eleusine coracana Gaertn). Journal of Agricultural and Food Chemistry $\mathbf{2 5}$, $1101-1104$.

Rubio, L. A., Brenes, A. \& Castan̆o, M. (1989). Histological alterations to the pancreas and the intestinal tract produced by raw faba bean (Vicia faba L. minor) diets in growing chicks. British Poultry Science 30, $101-114$.

Schaffert, R. E., Lechtenberg, V. L., Oswalt, D. L., Axtell, J. D., Picket, R. C. \& Rhykerd, C. L. (1974). Effect of tannin on in vitro dry matter and protein disappearance in sorghum grains. Crop Science 14, 640-643.

Singh, U. (1984). The inhibition of digestive enzymes by polyphenols of chickpea (Cicer arietinum L.) and pigeonpea (Cajanus cajan (L) millsp.). Nutrition Reports International 29, 745-753.

Tamir, M. \& Alumot, E. (1969). Inhibition of digestive enzymes by condensed tannins from green and ripe carobs. Journal of the Science of Food and Agriculture 20, 199-202.

Terpstra, K. \& De Hart, N. (1974). The estimation of urinary nitrogen and faecal nitrogen in poultry excreta. Zeitschrift für Tierphysiologie, Tierernährung und Futtermittelkunde 32, 306-320. 